\title{
J.J. Lubbe
}

\section{"BY PATIENCE, LABOUR AND PRAYER. THE VOICE OF THE UNSEEN GOD IN THE LANGUAGE OF THE BECHUANA NATION." A REFLECTION ON THE HISTORY OF ROBERT MOFFAT'S SETSWANA BIBLE (1857) ${ }^{1}$}

\section{ABSTRACT}

The translation of the Bible into Setswana by Robert Moffat in 1857 was the first in an African language in sub-Sahara Africa and also the first Bible to be printed here - at the mission station at Kuruman, 150 years ago. This Bible translation had an enormous influence, reaching the Batswana people in different countries in Southern Africa and is still held in high esteem by them. The question should be asked why? What made Moffat's Setswana Bible so popular? The relevant primary sources - collected and studied as the focus of this article - suggest that it might have been the daily life and work of this missionary and his wife for nearly half a century amongst the Batswana. Robert and Mary Moffat convinced "the Bechuana nation" to accept and read the Gospel in their own language, by living "the voice of the Unseen God".

\section{INTRODUCTION}

The following inscription appeared on the flyleaf of the 1872 Setswana Bible, in the possession of the Kuruman Moffat Mission:

The language of the Bechuana Nation in which nothing had ever been written, was by patience, labour and prayer acquired, and into that language, this the Holy Bible, the voice of the Unseen God, proclaiming redemption to all through the Lord Jesus Christ has been translated and now read by many thousands. Bless the Lord, o my soul (De Gruchy 1999:54).

1 Paper presented at a Theological Conference, "Is the Bible still relevant for the Southern African Society", at the Bible Society of South Africa, Bloemfontein, 26 October 2007.

Rev. J.J. Lubbe, Research Fellow in the Department of Church History, University of the Free State. 
Thus it was inscribed in the shaky hand of an elderly Robert Moffat. He was alone at the time, in Brixton, England, thousands of kilometres away from the small village of Kuruman, which bordered the arid Kalahari where he and his "beloved partner", Mary, had ministered the Word of God for half a century (Dickson 1989:216-218). His name was inextricably linked to the mission station and its surrounding settlement, to the Batswana in central Southern Africa and to their Bible translation. The Setswana Bible of 1857 was the first complete translation of the Bible into an African language and the first to be printed in Africa south of the Sahara. Moffat's return to England thirteen years later was partly for the reason of doing a final revision of his Bible translation; his life's work for which he would receive an honorary doctorate from the University of Edinburgh in that same year, 1872. Wherein lay the virtue of Robert Moffat's Bible translation?

This article will investigate the background to Moffat's Bible translation and the questions surrounding his years of labour. What had made his Bible translation so successful that "many thousands" wanted to read it? How did it happen that the "voice of the Unseen God" stirred the hearts of the "Bechuana nation"? To answer these questions, one should make a study of the primary historical sources, following a theological-critical approach. That which was written by Moffat, his contemporaries and his first biographer — his son, John S. Moffat - would inevitably be subjective, often apologetic in nature and written from the perspective of European missionaries of the nineteenth century, in terms of idiom and style.

A significant clue in answering these questions can be found at the place where the Moffats performed their life's work: the historical site of the mission station at Kuruman - "our little paradise in this wilderness country", as Mary described it in a letter in 1828 (Dickson 1989:83). Standing in the nave of the Moffat church - the "cathedral of the Kalahari" - and looking through the window, one can see the restored classroom of the small school building that had once stood to the west of the church. The foundations of the original school can still be seen today and in the southwestern corner a replica of the famous Moffat bust. It is here, in the restored classroom, that the original printing press stands today - one of the telling witnesses of the remarkable work that had been done there. Just next to the door, before entering the classroom, there is a small memorial stone tablet in a wooden frame on the wall bearing the following inscription: "Ba ba rubítseng mo go Jesus, Morimo. O tla ba lere nin."

Dating from 1825, this is the oldest written inscription in Setswana that has remained at Kuruman. It contains the words of Paul to the Christians in Thessalonica: "... and so we believe that God will bring with Jesus those who have fallen asleep in Him ..." (1 Thes. 4:14). 
To understand the touching significance of these words, it is necessary to retrace the steps to a more distant past in order to see where the story of Moffat and his Bible translation originated. The words on the stone tablet date from the first phase of his work there, in the decade before 1831.

For about thirty years up until then the Batlaping had had sporadic contact with white people from the Cape Colony: wanderers, hunters and official representatives of the colonial authorities, such as Truter and Somerville in 1801. Shortly after that, the first missionaries of the London Missionary Society (LMS), John Edwards and Jan Kok, settled at Gasegonyane Fountain and went on periodical visits to Dithakong ("Lattakoo"), an indigenous village with about 15000 Tswana inhabitants, 3000 huts and the seat of supreme chieftain Molehabangwe. Edwards and Kok conveyed their message in Cape Dutch a language also spoken by the Griqua in that area, so there were interpreters available to facilitate this contact with the Batswana. Amongst the Batlaping, wrote Edwards, there was "a knowledge of a Supreme Being as well as the existence of the devil ..." ("... eenige kennis van een Opperwezen, ook hebben zij een benaming ervoor, als ook voor den Duyvel ...", Smit 1966:15). That was also the impression of Lichtenstein, a traveller who wrote a few years later that the Batlaping revered a supreme being that they called "Morimo", but other than that they had "no religious worship". That was why, according to him, the first missionaries had little impact:

... and what benefit had been derived from his teaching (Kok), was in an improved method of tilling the ground, not in the adoption of Christianity (Smit 1966:18).

By 1808 the grave of the murdered Kok was all that remained in the tall grass near Gasegonyane Fountain, the only tangible evidence of this first mission. All was not totally forgotten by the Batlaping, however. Some years later the Rev. John Campbell from the LMS remembered a conversation with Mahutu, the wife of supreme chieftain Mothibi, at Dithakong in which she questioned him about the Bible, life after death and the dwelling-place of God (Campbell 1815:272-273). ${ }^{2}$ Some time after this conversation a request followed from Mothibi that the LMS at Griquastad send missionaries to his new seat of government at Maropeng (Moffat 1842:213-220). And so James Read, John Evans and Robert Hamilton arrived at Maropeng with its nearly 5000 Tswana inhabitants, the new "Lattakoo". Evans had a good grounding in French, Latin and Greek and a sound knowledge of Hebrew and Aramaic. After nine months, however, he finally lost heart and wrote to the LMS directors that he had given up and wanted to return to the Cape Colony. His reasons:

Cf. West 2009. 
Impossibility of arranging their rude speech into a proper form for to bear a translation of the Sacred Volume in my lifetime. But should they be civilised heathen and had a constructed language of their own, I should not have resigned it for the whole world ... I want to be a means of converting souls ... (Bradlow 1987:8).

The LMS was convinced of the validity of Evans' argument. Earlier on, Dr. $\mathrm{J}$. van der Kemp had compiled a spelling list and an elementary catechism in a Khoi dialect of the eastern Cape (1802), and at Lovedale, John Bennie's Systematic Vocabulary of the Kaffrarian Language was published in 1823. Read and Hamilton, who had stayed behind with the Batlaping, continued in their attempt to rewrite the "rude speech into a proper form". A first edition of an elementary Spelling Book in the Bechuana Language was printed by the missionary Henry Helm at Griquastad in 1819, compiled by the "brethren at Lattakoo" - the first book in Setswana! This spelling book was not widely used and no copies have remained. It was a year later when Read wrote to Campbell that even though they had been collecting many Setswana words and expanding their knowledge of the Setswana vocabulary, he considered himself to be "unfit" to translate the Bible into Setswana (Bradlow 1987:9-10). Interesting also, is the fact that Helm used Cape Dutch as well as Setswana in his missionary work. Many years later Moffat found believers amongst the Batlaping to whom Helm had given a Dutch translation of the New Testament, and to whom it still was the fountain of their belief, "the oil which makes my lamp burning ..." (Moffat 1842:620).

By 1820 Read and Hamilton were not alone at "New Lattakoo" anymore. In the autumn of that year their ranks were reinforced from the southwest by the arrival of a young man and his wife in an ox-wagon - Robert Moffat and his Mary.

\section{2. “... GROPING IN THE DARK ...” (1820-1831)}

Robert Moffat (1795) was of Scottish-Presbyterian descent. He had only a few years of school education behind him, supplemented by the religious instruction given to him by his pious mother (for more biographical facts, also see Sillery 1976:571-575). He had completed his apprenticeship to become a gardener at the age of fourteen. The congregational minister of Manchester, Rev. William Roby, had had an important formative influence on the young Robert. He prepared the young man theologically for his calling to become a missionary - a calling that grew stronger by the day. Finally, in 1816, Moffat was accepted as a missionary by the LMS and was sent to South Africa a year later - "self-taught, confident and twenty-one years old" (Butler 1999:38). Equipped with a command of the Dutch language that he had acquired during his sojourn in the Cape Colony, Moffat was sent to the arid western regions 
to the north of the Gariep: Great Namaqualand - a desolate landscape under the reign of the infamous Nama leader, Jager Afrikaner. During one of his travels through these regions Moffat had come into contact with the Batlaping at Dithakong, and he was sent there a year later (Moffat 1842:167).

The situation in which he found himself among the Batswana was unique, the young missionary wrote: there were no legends about the origin of all things, and there was no compulsory reverence of the forefathers, no sense of eternity, no cruel cult of sacrifice and "no altar to an unknown God" to serve as a starting-point for his ministry; "no sacred streams ... nor voluntary victims to propitiate the anger of imaginary deities". It was so different from his European background where it was generally accepted that there were "rays of natural light, innate ideas of a Divine Being" to be found in all people. His ministry was met up with ridicule or a total lack of response - it was as if his preaching disappeared like the water of the Kuruman river into the dry Kalahari sand. Having been told by Moffat that his soul was immortal, that it was God Who let the sun rise and the grass grow, a chieftain once shrugged this off by calling it "litlamane" (fables), following which he burst into "deafening laughter ..."! Moffat therefore had a sense of urgency in finding a name for God so that they would understand who the "Morimo" of the Batswana was. Later one of his converts would remark:

We had no idea that an unseen eye saw us, or that an unseen ear heard us. What could we know beyond ourselves, or of another world, before life and immortality were brought to us by the word of God? (Moffat 1842: 268, 252).

Some of the Batswana rituals seemed to Moffat to have had similarity to Mosaic laws from the Old Testament: "like shells without the kernel." The missionaries also repeatedly came up against the sayings and acts of a so-called "rainmaker", to whom the Batswana attached great value. During the parching drought of $1824 / 25$ one of the Batswana even stayed over at the mission station, challenging them with the question:

\footnotetext{
Where is your God? Have you not seen our Morimo? Have you not beheld him cast from his arm his fiery spears, and rend the heavens? Have you not heard with your ears his voice in the clouds? You talk of Jehovah, and Jesus — what can they do? (Moffat 1842:263-266, 311).
}

The limitations of ministering through interpreters, who could not read the Bible and who were not always accurate in their interpretations, caused Moffat endless frustration. It became a matter of urgency to learn to speak Setswana. On the one hand, this happened spontaneously because he was hearing Setswana along the way: while collecting wood and stone for the building of the two houses at Seoding, higher up the Kuruman River; while digging a furrow 
from the Gasegonyane Fountain to the mission station; while cultivating vegetable gardens and planting fruit trees; or while on hunting trips somewhere in the veld, "talking as they went" (Butler 1999:39), "a mixture of Dutch, Sechuana and English" (Bradlow 1987:5), three languages and cultures, worlds apart. Moffat recalls:

\begin{abstract}
... it was something like groping in the dark, and many were the ludicrous blunders I made ... After being compelled to attend to every species of manual and frequently menial labour for the whole day, working under a burning sun, standing on the saw-pit, labouring at the anvil, treading clay or employed in cleaning a water ditch, ... I was in no very fit condition for study ... (Moffat 1842:292).
\end{abstract}

On the other hand, he had little help in "the reducing of an oral language to writing". It was a severe trial for his faith; "a task of much labour", he wrote to the LMS in 1822: "There is not an interpreter who can give the proper meaning of a single sentence" (Bradlow 1987:5-6).

During the day Moffat's writing was interrupted by the noise of buildings under construction; a constant stream of beggars, hunters and wanderers passing through or stopping over; and by flies attracted to the ink, literally "drinking the ink as fast as it flowed from the point of the pen". And in the evenings, when the interpreters were exhausted as well, countless swarms of insects were attracted to the candlelight (Moffat 1842:460-461)! After six years Moffat concluded his language studies with a ten week stay among the Barolong at Tswaing (Morokweng) which his son described as "savage life". $\mathrm{He}$ returned to the mission station with renewed vigour. His Buka ea Likaelo tsa eintla (the Setswana "Spelling Book") and the Buka ea Pocho ea Tuto le Poluko tsa Yesu Kereste ("A Bechuana Catechism with translations of The Third Chapter of the Gospel by John, The Lord's Prayer and other passages of Scripture") were completed with great zeal. The catechism was a translation done of a work by Dr. William Brown and consisted of 136 questions and answers. The opening lines are significant:

Q: E mang yo ú rihile letsatsi ungweri le linaleri?

A: Elele Morimo (Moffat 1826:2).

Moffat used the Batswana's knowledge of nature as his starting-point:

Who gives the sun, moon and stars to you?

Morimo. The Lord God.

The first passage of the Scriptures that he translated, was John 3, testifying to his zeal to convert souls and lead them to a new life so that they could pray the "Our Father" in their mother tongue. The manuscripts were sent to the 
Cape to be printed, but "... as if our measure of disappointment was not full, they were by some mistake sent to England ..." (Moffat 1842:444).

With the arrival of these first Setswana books - the pocket-sized, hard cover catechisms - from London in 1826, a new day dawned for Moffat and his helpers. About 50 Batswana families were living at and in the vicinity of the mission station by then and more than a thousand higher up in the valley. The two houses where Moffat and Hamilton lived and the school building - also built of stone - had since been completed. During the daytime 40 Setswana children were taught to read and write. "There are already four Bechuanas who can read in their own language the first principles of the doctrine of Christ", Moffat wrote elatedly to his father in England. In the evenings another 40 adults arrived for lessons; "cheering up our drooping spirits ... and some we heard began to pray!" Moffat wrote gratefully. One of the temporary houses served as a church building and the attendance of the services was good. On the advice of a visiting missionary from the Cape, Moffat translated the first Dutch hymns into Setswana. More translations followed after that. The singing of these hymns was, according to Moffat, very pleasing to the Batswana and the missionaries. Encouraged by this, he began to realise that if he wanted a Setswana translation of the Bible he would have to do it himself. And so Moffat began to work on his translation of the Gospel of Luke. Why he started there, is an open question: was it because miracles and parables abound in the Gospel of Luke?

In one of the small villages he had a remarkable experience, which he described in a letter to the Bible Society (20 November 1836):

I have frequently listened with surprise to hear how minutely some, who were unable to read, could repeat the story of the Woman who was a sinner; the parable of the Great Supper, the Prodigal Son, and the Rich Man and Lazarus; and date their change of views to these simple but all important truths, delivered by the great Master Teacher (Northcott 1961:122).

There were lighter moments too. The Setswana for "lilies in the field" was "lilelea", which sounds exactly like "dililea" — "tarantulas, the long, hairy-legged spiders with a poisonous bite ..." And so Luke 12:27 read (according to information sent to the Bible Society on 5 March 1861): "Consider the tarantulas, which toil not, neither do they spin ...!" (Northcott 1961:122).

Moffat spent more and more of his time labouring in his small library. As the manuscript progressed, he began to use it in his Scripture readings during sermons (Moffat 1842:485, 1885:131-145, 156). Two years later, in 1829, the Evangelia Luka was completed.

That same year brought another highlight. "Daylight at last", as their first biographer called it (Moffat 1885:152). The fact that both Robert and Mary 
Moffat had learned to speak Setswana, opened the hearts of the Batlaping to the powerful message of the gospel. "The simple Gospel," Moffat observed, "now melted their flinty hearts." The powerful working of the Holy Spirit was experienced and the tiny school building serving as chapel at the time, "became a Bochim - a place of weeping" (Moffat 1842:496). Instead of "heathen songs and dancing", "the songs of Zion" echoed through the valley (Moffat 1885:154-155). On the first Sunday of July 1829, at a church service conducted entirely in Setswana, with no help from interpreters, the first converts were baptised. That evening the first twelve Batswana Christians at Kuruman celebrated Communion together - "an encouraging season to our souls" at the end of the ordeal that marked the first decade of Moffat's stay there.

In the 1820s the central regions of Southern Africa were plagued by drought, swarms of locusts and the violence of the Mfecane that was spiralling westwards, causing increased social instability (Davenport 1991:12-17). "At that period", the young Moffat wrote:

... the demon of war seemed to fly from people to people ... These were days of trial, and scarcely a missionary station escaped unscathed north of the Orange river (Moffat 1842:187).

And, added Mary in a letter to her father in July 1824: "Horror and devastation reign over the whole land, darkness covers it, and gross darkness the people" (Moffat 1885:125-126).

During these times of turbulence, when the Batlaping of Dithakong were suffering under the violence of the MmaNthatisi, the Moffats remained faithful to their Christian calling of peace. In 1828 for example, when Kuruman was threatened, it must have been a gripping scene to see Moffat witnessing to an armed and dangerous band of attackers, telling them that prayer was his only defence. After hours of tense negotiation, one of the leaders came to the fore, his head lowered, and instructed his followers to give back all the livestock that had been stolen from the Batlaping and the mission station. He had at first refused to meet Moffat face to face because he had experienced this missionary's kindnesses years before while on a visit to Namaqualand and was now feeling too ashamed. "The omnipotence of love", a grateful Moffat described it afterwards. On another occasion, when the mission station was attacked, five of the enemy were caught and brought to Moffat House:

... not to turn that into a prison, but only to be fed, to sit without either locks or doors, secure from rudeness or danger (Moffat 1842:564-565).

The mission station had become a place of refuge for the sickly and the wounded, for orphans and castaway children, for refugees and even a "rainmaker" who was under threat because of all his failures to predict and deliver 
rain. The message of the Gospel of love, grace and forgiveness had become tangibly evident along with the importance of honour and integrity. On one occasion, chieftain Mothibi used the example of the missionaries when addressing a crowd of Batlaping: the "missionaries were the only human beings in the world who do not steal cattle" (Moffat 1842:445)! Mary Moffat's biographer wrote:

... language itself is not enough. To be believed, the words that are spo-
ken must come from a source that carries conviction. Through a long
time of testing, the Bechuana had come to trust their missionaries. They
had watched them live up to their own precepts (Dickson 1989:91).

This brings us back to the memorial tablet on the wall of the school building, dating from the middle of that first decade of darkness and difficulty. Engraved on it is a date and an inscription wrenched from the hearts of the young Moffat family. It was the gravestone of their second child, their son Robert, who was only five days old when he died in August 1825, making him the first to be buried in the graveyard of the mission station. The message Robert and Mary tried to convey with their scant command of Setswana at the time, was carved in the stone as a means of comfort in their time of need: God will bring those who "have fallen asleep in Jesus" to life again, with Him (1 Thes. 4:14): "Ba ba rubítseng mo go Jesus, Morimo. O tla ba lere nin."

The Moffats' unwavering daily labour, pragmatic outlook on life and loving kindness to their fellow man, culminated in the first translation of the Bible into Setswana. Four years later the translation in paper format was completed the Gospel of Luke. The Moffats travelled to Cape Town to have it printed by the Government Printer. It was a milestone.

A new epoch in the missionary work under the Batswana had begun.

\section{3. “... THIS SEASON OF PLEASURE ...” (1831-1857)}

Robert Moffat returned to Kuruman in June 1831 with great joy and expectancy. Never before, he wrote, had a missionary's ox-wagon, loaded with such great "treasures" crossed the Gariep River: its "treasures" being the printed and bound Gospel of Luke in Setswana, a hymnal with 23 hymns in Setswana and a great quantity of paper and ink (Moffat 1842:563-565). Added to that were the donations of numerous supporters in the Cape for the building of a church; as well as fabrics, linen and wool to be used for a school where sewing skills would be taught. The greatest of all the gifts, however, came from Dr. John Philip of the LMS: a heavy iron printing press of unknown brand, but made in England, "so suitable for this climate..."

The mission station under Hamilton's guidance was in "a prosperous state". The number of Batswana that attended school and religious instruction 
grew by the day. Even though the "strong excitement" of 1829 had toned down somewhat, their knowledge of the Bible and the Christian faith had deepened. There was seriousness and an eagerness to learn - "the first-fruits of the Gospel among the Bechuana." Moffat remarked contentedly: "The spiritual affairs of the station kept pace with external improvements ..." $(1842: 559,565)$. The foundations of the church were laid in 1830 and everybody at and around the mission station wanted to lend a helping hand, either by donating an ox or a goat or by offering free labour for a month. It was soon evident that an additional wing would have to be added to the building. However, this would take another seven years to complete.

Meanwhile the printing press was put to work - the Batswana marvelled at it and referred to it as the "segathisho":

\begin{abstract}
... nothing could exceed their surprise when they saw a white sheet, after disappearing for a moment, emerge spangled with letters. After a few noisy exclamations, one obtained a sheet with which he bounded into the village, showing it to everyone he met, and asserting that Mr. Edwards and I had made it in a moment, with a round black hammer and a shake of the arm (Moffat 1842:478-491).
\end{abstract}

Robert Moffat was inspired more than ever before by his translations and writings and he now had the help of more competent assistants. To him, according to De Gruchy (2002:172-173), "the Church they were planting would be a Church nourished by the Word". The printing and binding was done in a living-room. There was always a shortage of lettering, especially in respect of the " $m$ " that is used as a prefix in so many Setswana words. The Spelling Book of 1826 was revised; and ten years later there were 4000 copies in circulation (Butler n.d.:12-13). Another catechism and Scripture Extracts for the use of Schools followed. The first "Hymn-book" now contained 100 hymns. The first series of tracts by Robert Edwards was printed in 1836. Travellers like Andrew Geddes Bain were immensely impressed by the vitality of the mission station and by the volume of work the hard-working printing press had produced. The Evangelia Luka had taken its course: Batswana, from as far as $100 \mathrm{~km}$ away, walked all the way to Kuruman to exchange a sheep or some spears for a copy of the Gospel. Women on a vigil next to the bedsides of dying parents or children, clung to their copies of the Evangelia, their hands wet with tears. And families at Taung, so it was told, would not leave their sickly to their cruel fate outside the village anymore, "because we heard the word of God at Kuruman." Strangers, coming from the north-east, found a refuge at the mission, convinced that God's loving Providence had led them to Kuruman. Chieftain Sechele of the Bakwena, $250 \mathrm{~km}$ away, sent his children to the little missionary school with the following message to the Moffats: "I know that you are kind hearted and gentle among the people of the land" (Dickson 1989:162). 
From even further north the feared Mzilikazi, king of the Matabele, sent messengers to Kuruman to see what was afoot - initiating a remarkable friendship that, coupled with a visit to the Matebele, served as a further incentive to Moffat to work even harder at translating and spreading the Gospel (Moffat 1842:510-557). A distant Koranna tribe even invited Moffat to come and stay with them "and to make books in their language, as I had done in the Sechuana." On another occasion a chieftain looked at Moffat questioningly and pointed at the Evangelia in Moffat's hand:

What is the precepts of that book which has made you what you are? ... And is it that mahuku a molemo (the good news) which has made your nation new ...? (Moffat 1842:503, 505, 569, 589-591, 602).

And from a distant outpost the missionary Hughes wrote to Moffat:

The great principles of the Bible Society are exemplified here, the simple reading and study of the Bible alone will convert the world. The missionary's work is to gain for it admission and attention, and then let it speak for itself. The simplicity of means in connexion with the greatness of the effect, is quite in character with its Divine Author. To Him be all the praise! (Moffat 1842:618).

From the halo of candlelight in the evenings and murmuring of the hardworking little printing press in daytime, The Epistle of James and the Gospel according to Matthew came forth. By 1838, when the stone church in the Kuruman valley was about to be consecrated, Moffat had completed his translation of the New Testament. For its final revision he and his family had to go to London - a journey that would take them three years, there and back. While in London, he wrote and published his well-known Missionary Labours and Scenes, addressed meetings of missionary friends and raised funds. At the $36^{\text {th }}$ annual meeting of the British and Foreign Bible Society he had the following to say:

It is said that spears shall be turned into pruning-hooks; and here figurative language of the prophecy is in some measure fulfilled: these books are as ploughshares, breaking the fallow ground of heathenism ... (Bradlow 1987:20).

The culmination of the Moffats' work in London was when they received the first copies of the New Testament in Setswana: 497 pages, double column. And their joy was twofold: not only could the first 40 copies of the New Testament be dispatched to the Cape, but also a new missionary to Kuruman - the youthful David Livingstone. In the meantime Moffat stayed behind to continue his work. The next 500 copies of the Setswana New Testament were supplemented by a translation of the Psalms with a revision of his Scripture Lessons following 
later as well: "... a selection from the Old and New Testaments, suited to the circumstances of the Bechwana churches" (Moffat 1885:231).

After having laboured in England for four years, the Moffats returned to Africa and "to their real home" - Kuruman. "They were Africans." Their reception at the mission station in 1843 was overwhelming: young and old celebrated, while tears of joy were streaming down their cheeks. More than twenty oxwagons, carrying Batswana Christians, arrived from the surrounding areas, among them the elderly Chief Mothibi. During the Moffats' absence, he had been converted to the Christian faith and had been baptised subsequently. "That Sabbath the chapel was filled to overflowing and four hundred sat down to communion" (Dickson 1989:136).

Kuruman was now home to many competent missionaries and their assistants - Hamilton, the Moffats and Edwards, the young William Ashton and his family as well as William Ross. Also not to be forgotten is the energetic David Livingstone, for whom there was always a new frontier to be discovered. Independent churches were established further to the north: at Kanye, Molepolole and Shoshong as well as Inyati in Zimbabwe. Moffat appointed Batswana teachers to these small churches and schools, and remained in contact with them through regular correspondence. Shomolekae, who was born at Kuruman and who was one of the first Batswana to be baptised there, became the missionary in Ngamiland. Livingstone though, was dubious of whether the Batswana would remain an independent nation with their own culture, and whether the timeconsuming translation his now father-in-law was labouring on, had any merit:

... a monument of devotedness and zeal in a language which (in a few decades - JL) no living jaws can articulate nor mortal understand (Bradlow 1987:10).

But Robert Moffat was not deterred from his original intentions. And although it was "a season of pleasure" in the Kuruman valley, trials and afflictions like the smallpox epidemic, yet another drought and increasing tension between the Batlaping and the Transvaal farmers, required a great deal of strength and perseverance. Furthermore, on his way home after a service one evening, Moffat was attacked by a stranger with a knobkierie. Throughout all of this however, reprints of the Spelling Book, catechisms, Hymn Book and tracts were produced by the small printing press, resulting in more than 103 different editions and publications! $!^{3}$ Amongst them was also a translation of the famous Pilgrims Progress written by John Bunyan, which was unfortunately not as popular with the Batswana. But the "one thing that held the whole creative activity at Kuruman together for a full forty years", Alan Butler (1999:43) wrote,

3 For a complete list of publications of the Kuruman printing press, see Northcott, C. Life and Work of Robert Moffat (1961), and printed in Bradlow (1987:26-36). 
"was the slow, painstaking work of translating the Bible". Determinedly the fifty-year old Moffat, aided by the competent young William Ashton, translated book after book of the Old Testament: Proverbs, Ecclesiastes, Isaiah (1847); Genesis and Exodus (1851); Leviticus to the Second Book of Kings (1853). In his letters to his children (on 20 August 1856) he complained that the work on the translations was slowed down by the usual interruptions: someone wanting a tooth extracted; another wanting a letter of consent to travel to the Cape; yet another wanting to have the breech of his gun repaired; and then of course visitors from the deeper inland territories would arrive (Moffat 1885:314-315).

Added to that, Moffat's knowledge of Hebrew was not always up to standard. Many years later his son, John S. Moffat, remarked that there was at least one error on every page of the translation! But on 16 September 1857 his work was done: the Bibela ea Boitsepho. "... by labour, patience and prayer ... the voice of the Unseen God, in the language of the Bechuana Nation."

The Word of God was available in yet another language of man. By then the Word of God had been in the hands of the Batswana for three decades and had been spoken in their tongue. From Shoshong another LMS missionary, John MacKenzie wrote to Moffat in 1874 about the effect the Great Book had on young people in his surrounds; young people who, in a manner of speaking, "have entered into the Word", and now became known as: "... bathu ba bhuku ..."(Dachs 1975:100-101) (People of the book).

"To the translator" his son remembered, "the labour had been simply Herculean" (Moffat 1885:318). And there was a heaviness in the translator's heart. By the end of the winter, in August 1856, Moffat wrote about his feelings of disquiet to his children ...

\section{4. “... THE TIME OF EBB WITH US ...” (1858-1872)}

By the end of the 1850s to the northeast of Kuruman, tension was growing between the Transvaal Boers and the Bakwena headed by Chieftain Sechele. The mission station at Shoshong fell prey to the outbreak of violence. To the east, in the Free State, the Barolong were under pressure. During the following years Moffat would travel to both of these groupings repeatedly, trying to establish peace and justice for all. Concerning their position at Kuruman Moffat wrote the following to his children on 20 August 1856:

It is the time of ebb with us ... Few have been added to our churches, notwithstanding the increase of means in the way of books and, I might add, good congregations and attentive hearers. There is a general deadness over which we mourn. We feel we need the kindling influences of the Holy Spirit. The public mind has been greatly soured by the policy of our Government towards the native tribes on the northern 
border, who have never given the shadow of a reason for being so dealt with ... The members of our churches of course know that this is no fault of ours, though we are sadly ashamed of it, and can no more open our mouth to say a single word in favour of our nation, once so respected and honoured by the aborigines ... (Moffat 1885:316).

The "scramble for Africa" had begun. In his study, next to the water furrow lined with syringa trees at the Kuruman mission station, the deeply concerned Moffat continued his daily labours. His own copy of the 1857 Bible was filled with notes and corrections in his own hand. ${ }^{4}$ His next decade was devoted to a revision of the New Testament, of which 50 copies were printed at Kuruman in 1867. With that, the complete Setswana Bible had been printed on the little press at the mission - a first for Africa south of the Sahara. A life's mission had been completed. And yet: the Old and New Testament still comprised two volumes. To have these printed and bound in one volume would have to be done in England. By then Robert Moffat was advanced in years. The London Missionary Society wanted him to travel all the way to England to have this done:

Away in the north Moselekatse, king of the Matebele, died. An era ended for his people. An era too was ending at Kuruman, where his old friend, Moshete and his wife MaMary, faced a more difficult turning on life's inexorable path ... (Dickson 1989:54).

On 20 March 1870 an aged Moffat delivered his last sermon in the packed stone church. The Kuruman valley bade Robert and Mary farewell with the deepest respect. He had brought them the "voice of the unseen God" in their own language. Two years later, the first edition of the complete Setswana Bible in one volume, saw the light. It was on this Bible's flyleaf that Moffat wrote: "Bless the Lord, o my soul" (De Gruchy 1999:54).

But by then, Robert was alone. A few months after their arrival in England, Mary had passed away. Moffat said to Mrs. Pitman on October 2, 1879: "I am an African,' he wrote to a friend" (Northcott 1961:322).

\section{CONCLUSION}

The work on the Setswana Bible continued after 1872. A first reprint of the Moffat translation was published in 1890 and a second reprint in 1894, containing a new orthography. A revision committee consisting of John Brown, Roger Price and Alfred Wookey, was appointed three years later. The result of their efforts, completed in the new century (1908), became known as the "Wookey-Bible". By then the old printing press at Kuruman had already fallen silent for nearly a decade. During the next fifty years several efforts were

4 In possession of the Africana Library, McGregor Museum, Kimberley. 
made at revising the New Testament. Eventually, in 1970 - a century after Robert Moffat's departure from Kuruman - the Bible Society of South Africa published a new, complete translation of the Bible in "Central Setswana".

On reading this history, one's thoughts inevitably go back to Kuruman and the Mission. To this day pilgrims travel there in need of peace and solitude, to listen to the Word of God - "the voice of the Unseen God" - in the stillness inside that historical stone church or in the tranquil shade of the tall trees outside. And they remember the "Apostle of the Bechuana" whose daily life was the first translation of the Bible for the Batswana. Therein lay the virtue of his labour.

Therefore it was fitting to name the modern library, built to the western side of the Moffat Mission in 1987 for the use of the Kalahari Desert School of Theology, after Robert Moffat. A stained-glass window, salvaged from a church in Kimberley that had to close down because of apartheid laws, was fitted into its northern wall depicting the crucified Christ. The text - engraved by the Rev. Alan Butler at the bottom of the window - bears witness to the Christian hope, a new day: "Ba ba robetseng mo go Jesu, Modimo otla ba lere nae ..."

This is the very same text that was engraved by Robert and Mary Moffat on their son's gravestone in 1825 and printed in the 1857 Setswana Bible. Still today, it is the living Word of God for the Batswana people of Southern Africa: the Word that became flesh and lived for a while amongst us (John 1:14). That indeed, was the first translation of his Holy Voice in Setswana.

\section{BIBLIOGRAPHY}

Bible Society of Southern Africa

1989. The history of the Setswana Bible. Roggebaai: BSSA.

BradLow, F.R.

1987. Printing for Africa. The story of Robert Moffat and the Kuruman press. Kuruman: Moffat Mission Trust.

ButLer, A.

s.a. Kuruman Moffat Sending. Historiese oorsig. Kuruman: Moffat Sending Trust.

1999. Kuruman: The work of the LMS in Bechuanaland. In: S. de Gruchy (ed.), Forty days in the desert. Biblical meditations from Moffat Mission on the edge of the Kalahari (Gaborone: Pula Press), pp. 38-48. 
Campbell, J.

1815. Travels in South Africa. Undertaken at the request of the Missionary Society. London: Black and Parry.

DACHS, A.J. (ED.)

1975. Papers of John MacKenzie. Johannesburg: Witwatersrand University Press.

DAVENPORT, T.R.H.

1991. South Africa: A modern history. London: Macmillan.

De Gruchy, S. (ED.)

1999. Forty days in the desert. Biblical meditations from Moffat Mission on the edge of the Kalahari. Gaborone: Pula Press.

2002. Dissenting Calvinism. Reflections on the congregational witness in South Africa as part of the wider Reformed tradition. In: P. Coertzen (ed.), 350 Years Reformed (1652-2002) (Bloemfontein: CLF), pp. 67-177.

Dickson, M.

1989. Beloved partner. Mary Moffat of Kuruman. A biography based on her letters. Kuruman: Moffat Mission Trust.

MofFAT, J.S.

1885. The lives of Robert \& Mary Moffat. With portraits and maps. London: T. Fischer Unwin.

Moffat, R.

1826. A Bechuana Catechism with translations of The Third Chapter of the Gospel by John, The Lord's Prayer, and other passages of Scripture, etc. Holborn: J. Deonett. A copy preserved in the Africana Library, McGregor Museum, Kimberley.

1842. Missionary labours and scenes in Southern Africa. London: John Snow.

1857. Bibela ea Boitsepho. London: LMS.

NoRTHCOTT, C.

1961. Robert Moffat: Pioneer in Africa 1817-1870. London: Butterworth Press.

SiLLERY, A.

1976. Robert Moffat. In: W.J. de Kock (ed.), Suid-Afrikaanse Biografiese Woordeboek I (Cape Town: Tafelberg Publishers), pp. 571-575.

SMIT, A.P.

1966. Wateroog in die Dorsland. Ned. Geref. Kerk Kuruman 1916-1966. Kuruman: Kerkraad van die NG Kerk.

West, G.

2009. The beginning of an African biblical interpretation: the Bible among the Bathlaping. Acta theologica Supplementum 2, pp. 33-47. 
Lubbe

Robert Moffat's Setswana Bible

Keywords

Trefwoorde

Setswana Bible

Setswana Byble

Robert Moffat

Robert Moffat

Kuruman

Kuruman 